\title{
Fragmento del Monólogo (Hamlet: Acto III, Escena I.)
}

Ser 0 no ser, he aquí el problema.

Acaso vale más sufrir los golpes que, cual flechas, nos envía la suerte,

$u$ oponerse a ellos -inagotable mar-

hasta vencerlos. Morir... dormir...

y nada más; y así, con el dormir, pretender que termina el dolor y los miles de golpes y dolores

que la carne ha heredado, final que constituye

nuestro mayor deseo. Morir... dormir...

¡Dormir! ¡Soñar quizás! Tal el escollo

porque de tal sueño de la muerte,

desvanecido ya nuestro mortal trabajo,

algún sueño quedará que multiplique

nuestro dolor. Pues ¿quién resistiría

los golpes y las burlas del tiempo, los abusos del tirano, la debilidad del orgulló las penaš dē un- despreciado amor, la lentitud de la justicia, Ta malevolencia del gobierno, las vejaciones que recibe el honradondefríndigno, cuando él mismo, con desnudo estilete, podría darse la quietud? ¿Quién podría llevar todo este peso de quejas y trabajos de lastimosa vida

si no fuera por el temor de lo secreto

del más allá de la muerte, de aquel lugar

del cual ningún viajero vuelve,

que atemoriza nuestra voluntad

$y$ nos hace soportar estas penas

en vez de arrojarnos a otras aún desconocidas?

Así, pues, nos acobarda la conciencia,

la razón vence a la enfermiza y débil voluntad,

las grandes decisiones se sustraen y no hay acción.

(Traducción de Francisco Carrillo) 